\title{
CTNND2 wt Allele
}

National Cancer Institute

\section{Source}

National Cancer Institute. CTNND2 wt Allele. NCI Thesaurus. Code C82942.

Human CTNND2 wild-type allele is located 5p15.2 and is approximately $932 \mathrm{~kb}$ in length. This allele, which encodes catenin delta-2 protein, plays a role in the modulation of both signal transduction and transcription. Copy number variation for the gene is associated with schizophrenia. 